\title{
Physiology of Bhendi Yellow Vein Mosaic Disease Infected Plant
}

\author{
K. Kalaichelvi*, J. Prabhaharan and D. Sambasiva Rao \\ Agricultural College and Research Institute, Madurai -625 104, India \\ *Corresponding author
}

\section{A B S T R A C T}

\section{Ke y w o r ds \\ Bhendi, Yellow Mosaic Disease, No Photosynthesis, Good transpiration rate and stomatal conductance \\ Article Info \\ Accepted: \\ 17 August 2020 Available Online: \\ 10 September 2020}

The major production constraint for okra is yellow vein mosaic disease, causing losses with regard to the quality and as well as the yield. This is a viral disease occurring on bhendi. Yellowing of the entire network of veins in the leaf blade is the characteristic symptom. In severe infections, the younger leaves turn yellow to become entirely chlorotic and the plant is highly stunted. Hence, we have studied the photosynthetic rate, Transpiration rate and Stomatal conductance in the virus infected plant and was compared with the non - infected plant with same moisture content. There was a very high difference in the photosynthetic rate of infected plant and healthy non -infected plant. Virus infected plant was recorded with zero photosynthetic rate $(-0.71)$ and healthy plant was recorded with a photosynthetic rate of 11.29 at the fruit development stage of bhendi. At the same moisture content, the transpiration rate of infected plant was near equivalent to the healthy non infected plant which confirmed that the transpiration and stomatal conductance is occurring in infected plant and only the disturbance in the plant system is due to lack of chlorophyll and photosynthesis.

\section{Introduction}

The major production constraint for okra is yellow vein mosaic disease, causing losses with regard to the quality and as well as the yield wherever the crop is grown. This is a viral disease occurring on bhendi (Okra/Lady's Finger). Yellowing of the entire network of veins in the leaf blade is the characteristic symptom. In severe infections, the younger leaves turn yellow to become entirely chlorotic and the plant is highly stunted. The veins of the leaves will be cleared by the virus and interveinal area becomes completely yellow or white. The veins become considerably thickened. The infection may start at any stage of plant growth. Infection restricts flowering and fruits, if formed, may be smaller and harder. The affected plants produce fruits with yellow or white colour and they are not fit for marketing. Bhendi vein clearing virus is a serious disease of Bhendi and causes huge economic loss. The yellow vein mosaic disease of okra (YVMD) is caused by Bhendi yellow vein mosaic virus (BYVMV) and was first reported in 1924 from the erstwhile Bombay Presidency (Kulkarni, 1924). The virus belongs to the genus Begomovirus, family Geminiviridae (Fauquet and Stanley, 
2005). Recently, BYVMD complex was shown to be associated with the virus with a genomic component typical of monopartite begomoviruses, homologous DNA A and a single-stranded betasatellite (Jose and Usha, 2003). This species is believed to have originated from India (Usha, 2008) and its only known methods of transmission are through whitefly (Bemisia tabaci Gennadius) and grafting. The DNA A component has seven open reading frames encoding several multifunctional proteins involved in rolling circle replication, gene transcription, cell-tocell and long-distance movement, suppression of host gene silencing, and encapsidation of the viral genome (Lazarowitz, 1992). Betasatellites are approximately half the size of their helper begomoviruses required to induce typical disease symptoms in their original hosts (Briddon et al., 2001). A survey on begomoviruses associated with okra in India revealed that the occurrence of YVMV incidence ranged from 23.0 to $67.67 \%$ in Karnataka, 45.89 to $56.78 \%$ in Andhra Pradesh, 23 to $75.64 \%$ in Tamil Nadu, 42.45 to $75.64 \%$ in Kerala, 23 to $85.64 \%$ in Maharashtra, 24.85 to $65.78 \%$ in Haryana, 35.76 to $57 \%$ in Uttar Pradesh, $45.45 \%$ in Delhi, $67.78 \%$ in Chandigarh and 45.89 to $66.78 \%$ in Rajasthan (Venkataravanappa, 2008). The weather condition in India is more congenial to the vector whitefly survival throughout of the region i.e. the warm and humid condition. Another issue is that whitefly is polyphagus in nature resultantly survive on other crop. Hence, we have documented the physiology of infected plant and non - infected plant.

\section{Materials and Methods}

In a standing bhendi seed production plot at $\mathrm{B}$ Block, Agricultural College and Research Institute, Madurai, there was severe infection with bhendi yellow mosaic disease and the observation on photosynthetic rate,
Transpiration rate and stomatal conductance was recorded in healthy and virus infected crop using IRGA, Photosystem II Lci T model on 24.8.2020 between 10.00 and 10.30 am. The $\mathrm{CO}_{2}$ concentration in the atmosphere is about $472 \mathrm{ppm}$ at the time of observation. The difference in the photosynthetic efficiency with virus infected and non infected plant is reported (Fig. 1 and 2).

\section{Results and Discussion}

Observation on photosynthetic rate, Transpiration rate and Stomatal conductance was observed in Bhendi yellow mosaic virus infected plant and non - infected plants and was given in the Table 1 .

The results revealed that there was a very high difference in the photosynthetic rate of infected plant and healthy non infected plant. Virus infected plant was recorded with zero photosynthetic rate also $(-0.71)$ and healthy plant was recorded with a photosynthetic rate of 11.29 at the fruit development stage of bhendi. There was no moisture stress in the field and the transpiration rate of infected plant was near equivalent to the healthy non infected plant which revealed that the transpiration and stomatal conductance is occurring in infected plant and only the disturbance is due to lack of chlorophyll and photosynthesis.

This was in accordance with the findings of Koiwa et al., (1992) reported that virus infection inhibits PSII activity selectively by the decomposition of light harvesting antenna complex of PSII (LHCII), based on their findings on the ratio of particles in the surface of the thylakoid membranes in tomato plants infected with TMV. Similarly, Eupatorium makinoi leaves infected with tobacco leaf curl geminivirus (TLCV) the amount of LHCII decreased in the chloroplasts (Funayama et al., 1997). 
Table.1 Physiology of virus infected and healthy non - infected plants in Bhendi

\begin{tabular}{|c|c|c|c|}
\hline Description & $\begin{array}{c}\text { Photosynthetic rate } \\
\mu \mathrm{mol} / \mathrm{m}^{2} / \mathrm{Sec}\end{array}$ & $\begin{array}{c}\text { Transpiration rate } \\
\mathrm{m} \mathrm{mol} / \mathrm{m}^{2} / \mathrm{Sec}\end{array}$ & $\begin{array}{c}\text { Stomatal Conductance } \\
\mathrm{mol} / \mathrm{sec}\end{array}$ \\
\hline \multicolumn{4}{|c|}{ Virus infected plant } \\
\hline 1. & -1.65 & 6.99 & 0.38 \\
\hline 2. & -2.19 & 3.67 & 0.14 \\
\hline 3. & 1.04 & 6.64 & 0.34 \\
\hline 4. & -0.94 & 4.40 & 0.21 \\
\hline 5. & 0.21 & 6.49 & 0.29 \\
\hline Mean & -0.71 & 5.64 & 0.27 \\
\hline \multicolumn{4}{|c|}{ Healthy Non - infected plant } \\
\hline 1. & 4.92 & 6.56 & 0.38 \\
\hline 2. & 7.00 & 7.94 & 0.50 \\
\hline 3. & 13.18 & 7.27 & 0.42 \\
\hline 4. & 18.10 & 6.84 & 0.81 \\
\hline 5. & 13.26 & 6.20 & 0.27 \\
\hline Mean & 11.29 & 6.96 & 0.48 \\
\hline
\end{tabular}

Fig.1 Bhendi Mosaic Infected

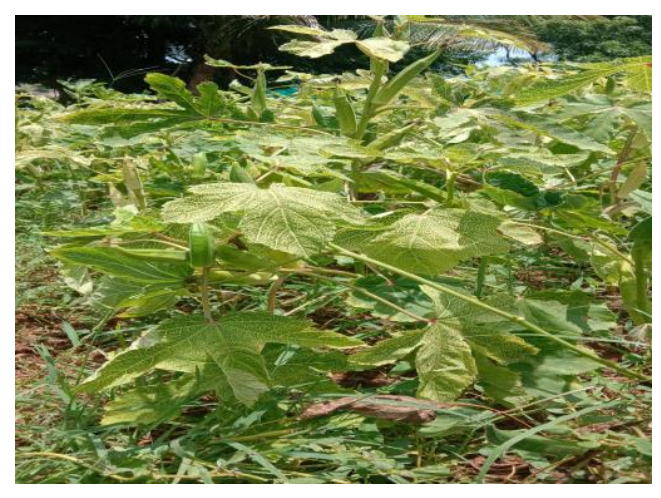

Fig.2 Healthy plant

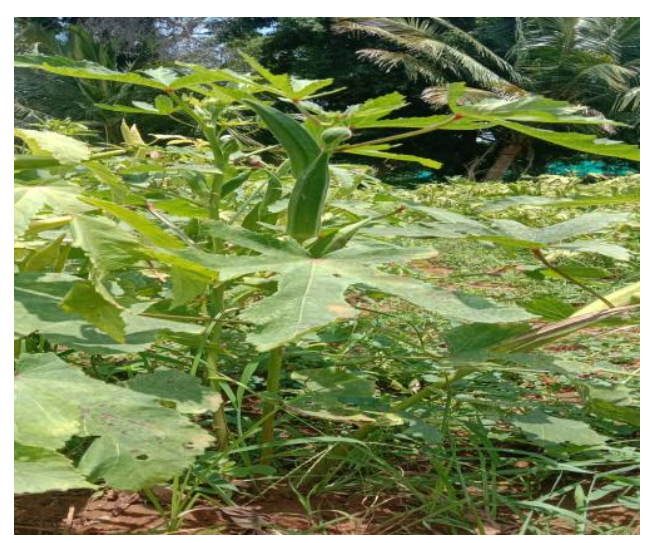


The same changes as well as the increase of respiration were observed in tobacco leaves infected with tobacco etch potyvirus (TEV) (Hopkins and Hampton, 1969). Depending on the time of inoculation, the plastids differentiated irregularly. The ratio of degenerated plastids changed with the time course of symptom development. The myelinlike or tubular structure was not formed by the disruption of the existing lamellae, but by their irregular development. In the case of BSMV infected etiolated barley seedlings we reported not only the accelerated senescence but the inhibition of chlorophyll biosynthesis (Almási et al., 2000).

Virus infection resulted in decreased photosynthesis (c. 50\%). Stomatal limitation was unaffected in virus-infected plants, demonstrating that stomatal closure was not causing photosynthesis decreases. Chlorophyll fluorescence and limitation analysis suggested that the inhibition of primary light reactions was only a minor effect of virus infection. By contrast, mesophyll conductance to $\mathrm{CO}_{2}$ and Rubisco activity substantially decreased in virus- infected plants, corresponding to increases in the limitations to photosynthesis imposed by mesophyll conductance and carboxylation. For the synthesis of virions the parasite uses the metabolites and energy of the host plant, which are produced in the course of photosynthesis. It is evident that the physiological processes of the virus and the plant are linked in complex ways, the structure and the function of the chloroplasts are disturbed (Zaitlin and Hull, 1987). Disturbances in the translocation of the photosynthetic assimilates may be related to the synthesis of viral movement protein (MP) (Lucas et al., 1993). As the infection had been progressed this tendency inverted: $\mathrm{CO}_{2-}$ uptake was decreasing in the infected tissues (Doke and Hirai, 1970).
In conclusion, there was a very high difference in the photosynthetic rate of infected plant and healthy non -infected plant. Virus infected plant was recorded with zero photosynthetic rate $(-0.71)$ and healthy plant was recorded with a photosynthetic rate of 11.29 at the fruit development stage of bhendi. At the same moisture content, the transpiration rate of infected plant was near equivalent to the healthy non infected plant which confirmed that the transpiration and stomatal conductance is occurring in infected plant and only the disturbance in the plant system is due to lack of chlorophyll and photosynthesis.

\section{References}

Almási, A., Apatini, D., Bóka, K., Böddi, B. and Gáborjányi, R. 2000: BSMV infection inhibits chlorophyll biosynthesis in barley plants. Phys. Mol. Plant Path. 56: 227-233.

Amit Kumar, R. B. Verma, Ravi Kumar, Saksham Kumar Sinha and Randhir Kumar, 2017. Yellow Vein Mosaic Disease of Okra: A Recent Management Technique. International Journal of Plant \& Soil Science 19(4): $1-8$.

Briddon RW, Bull SE, Amin I, Idris AM, Mansoor S, Bedford ID, Dhawan P, Rishi N, Siwatch SS, Abdel-Salam AM, Brown JK, Zafar Y, Markham PG. 2003. Diversity of DNA beta: a satellite molecule associated with some monopartite begomoviruses. Virology. 312:106-121. doi: 10.1016/S00426822(03)00200-9.

Doke, N. and Hirai, T. 1970. Radioautographic studies on the photosynthetic $\mathrm{CO} 2$ fixation in virusinfected leaves. Phytopythology 60, 988-991.

Fauquet CM, Stanley J. 2005. Revising the way we conceive and name viruses 
below the species level: a review of geminivirus taxonomy calls for new standardized isolate descriptors. Arch Virol.150:2151-2179. doi: 10.1007/s00705-005-0583-0.

Funayama, S., Hikosaka, K. and Yahara, T. 1997. Effects of virus infection and growth irradiance on fitness components and photosynthetic properties of Eupatorium makinoi (Compositae). American J. Botany 84, 823-829.

Hopkins, D. L. and Hampton, R. E. 1969. Effects of tobacco etch virus infection upon the dark reactions of photosynthesis in tobacco leaf tissue. Phytopathology 59, 1136-1140.

Jose J, Usha R. 2003. Bhendi yellow vein mosaic disease in India is caused by association of a DNA $\beta$ satellite with a begomovirus. Virology. 305: 310-317. doi: 10.1006/viro.2002.1768.

Koiwa, H., Kojima, M., Ikeda, T. and Yoshida, Y. 1992: Fluctuations of particles on chloroplast thylakoid membranes in tomato plants infected with virulent or attenuated strain of tobacco mosaic virus. Ann. Phytopath. Soc. Japan 58, 58-64.

Kulkarni CS. 1924. Mosaic and other related diseases of crops in the Bombay Presidency. Pune: Poona Agriculture
College Magazine p. 16.

Lazarowitz SG. 1992. Geminiviruses: genome and structure and gene function. Rev Plant Sci.; 11:327-349. doi: $10.1080 / 07352689209382350$.

Lucas, W. J., Olesinski, A., Hull, R. J., Haudenshield, J. S., Deom, C. M., Beachy, R. N. and Wolf, S. 1993. Influence of the tobacco mosaic virus $30-\mathrm{kDa}$ movement protein on carbon metabolism and photosynthate partitioning in transgenic tobacco plants. Planta 190, 88-96.

Sampol,B., J. Bota,D. Riera, H. Medrano and J. Flexas, 2003. Analysis of the virusinduced inhibition of photosynthesis in malmsey grapevines. New Phytologist 160 (2):403-412

Usha R. 2008. Bhendi yellow vein mosaic virus. In: Rao GP, Kumar PL, HolguinPena RJ, editors. Characterization, diagnosis \& management of plant viruses. Houston: Studium Press; pp. 387-392.

Venkataravanappa V. 2008. Molecular characterization of okra yellow vein mosaic virus. $\mathrm{Ph}$ D. thesis, GKVK, Bengalure.

Zaitlin, M. and Hull, R. 1987. Plant virus-host interactions. Ann. Rev. Plant Physiol. 38, 291-315.

\section{How to cite this article:}

Kalaichelvi, K., J. Prabhaharan and Sambasiva Rao, D. 2020. Physiology of Bhendi Yellow Vein Mosaic Disease Infected Plant. Int.J.Curr.Microbiol.App.Sci. 9(09): 2284-2288. doi: https://doi.org/10.20546/ijcmas.2020.909.284 